\title{
Legemiddelshopping
}

Opprettelsen av Reseptregisteret i 2004 har gitt oss unike muligheter for legemiddelepidemiologisk forskning i Norge. I fjor mottok Reseptregisteret ved Nasjonalt folkehelseinstitutt ca. 40 søknader om bruk av data i forskningsøyemed, og etterspørselen er økende (K. Furu, personlig meddelelse). En undersøkelse basert på kreativ bruk av slike reseptregisterdata er Rolf B. Winther \& Jørgen G. Bramness' undersøkelse som blir presentert i dette nummer av Tidsskriftet (1). Forfatterne kartla hvor mange leger enkeltpasienter hadde benyttet for å få forskrevet ett og samme vanedannende legemiddel. De sammenliknet forskrivningsmønsteret for tre potensielt vanedannende legemidler (diazepam, karisoprodol og kodeinkombinasjoner) med tre legemidler som ikke regnes som vanedannende (esomeprazol, metformin og salbutamol). Ikke uventet fant de betydelige forskjeller.

Forskrivning av potensielt vanedannende medikamenter, såkalte B-preparater, er et tveegget sverd. Brukt på riktig indikasjon til riktig tidspunkt er de en velsignelse. Men vi vet at medikamentene har potensial til å brukes i rusøyemed, og da gjerne sammen med andre rus- eller legemidler. Og vi vet at effekten taper seg ved fast bruk over tid, slik at dosen vil måtte økes for å oppnå den ønskede virkningen. Langvarig bruk er særlig betenkelig hos eldre, pga. sedasjon med fare for fall og påvirkning av kognitive funksjoner. Det er derfor offisiell politikk at forskrivning av B-preparater skal skje i lavest mulige dose og for en avgrenset tidsperiode (2), hvilket også ser ut til å samsvare med holdningen hos de fleste allmennleger (3). For en liten gruppe pasienter blir dette problematisk. De får ikke de medisinene de ønsker/trenger, og de forsøker seg dermed som såkalte «legemiddelshoppere», dvs. de oppsøker en rekke leger for å få sin forskrivning. Selv om dette gjelder svært få pasienter (1), er jeg sikker på at de fleste allmennleger - $\mathrm{i}$ likhet med undertegnede - godt kjenner til den ubehagelige følelsen av å ha blitt presset eller «lurt» til en forskrivning vi ikke var bekvemme med, gjerne ved hjelp av en hjerteskjærende historie.

Jeg er også rimelig sikker på at mange kolleger deler mitt ubehag ved å skulle opptre som «reseptpoliti»og sende pasienten på dør med uforrettet sak. Det er derfor positivt at fastlegeordningen har gjort det enkelt for allmennleger som en hovedregel å avslå forskrivning til pasienter utenfor egen liste. Winther \& Bramness finner da også at de aller fleste som fikk forskrevet vanedannende medikamenter, kun hadde benyttet én lege. Men likevel: 2-4\% av pasientene hadde vært hos flere enn to leger - det maksimale antall var 25. Og jo flere leger pasienten hadde vært hos, desto større mengde legemiddel var blitt utlevert og jo større var totalforbruket av benzodiazepiner og opioider. Hvorvidt eller i hvilken grad slik legemiddelshopping faktisk er blitt redusert med fastlegeordningen, har vi ikke eksakte kunnskaper om. Men i en omfattende registrering i Oslo og Akershus i 1993 fant man at kun 30 av totalt ca. 4000 leger hadde en forskrivning av benzodiazepiner og sterke analgetika over det nivå man definerte som for høyt (mer enn 4000 definerte døgndoser per måned) (4). Dette lave antall leger var ansvarlig for hele $13 \%$ av den totale forskrivningen. De var alle allmennleger og de var antakelig utsatt for en betydelig pågang fra legemiddelshoppere. Undersøkelsen tyder altså på at de aller fleste leger hadde en restriktiv forskrivningspraksis allerede før fastlegeordningen.
Interessant nok viste det seg i en annen undersøkelse at holdningene til å forskrive B-preparater ikke var annerledes hos de legene som hadde et høyt forskrivningsnivå i forhold til de øvrige (3). Det ble funnet høy grad av konsensus om hvordan en «god og riktig» forskrivningspraksis skulle være. Høyforskriverne var klar over at deres eget forskrivningsnivå avvek fra idealene, men de legitimerte dette ved å skylde på omstendigheter, for eksempel at de hadde overtatt storforbrukende pasienter fra andre leger. Storforskriverne hadde også en tendens til å legge vekt på det vanskelige og uløselige i pasientens situasjon, mens lavforskriverne heller la vekt på pasientens evne til mestring.

Hvor bør da støtet settes inn hvis vi skal forsøke å snu det økende forbruket av vanedannende medikamenter i Norge? Formelle reguleringer kan være effektive til en viss grad, slik som avregistreringen av karisoprodol og omgjøringen av flunitrazepam til å bli A-reseptpliktig. Retningslinjer for forskrivning finnes allerede (2), og det kan se ut som om flertallet av legene har holdninger som samsvarer med disse (3). Innføring av fastlegeordningen har ikke sammenfalt med noen nedgang i den totale forskrivningen av B-preparater. Skal det monne, må vi antakelig gå veien om å påvirke publikums holdninger. Legemiddelforskrivning er legens ansvar, men pasientmedvirkning og pasientautonomi gjør seg sterkt gjeldende i dag. Slik holdningspåvirkning drives for tiden når det gjelder antibiotikabruk: «Ikke pille for alt som er ille!» og «Antibiotika bare når det trengs!» (5) og har vist seg å være effektiv (6). Antibiotikakampanjen ser ut til å seile i medvind, dvs. å samsvare med trender som allerede finnes i befolkningen og som merkes godt for de av oss som behandler febersyke barn på legevakt. «Ikke valium for alt som er ille!» og «Sovepille bare når det (absolutt) trengs!» har foreløpig ikke samme gjennomslagskraft. Men argumentasjonen bak rådene skulle være minst like god.

\section{Mette Brekke}

mette.brekke@medisin.uio.no

Mette Brekke (f. 1953) er dr.med. og spesialist i allmennmedisin. Hun er førsteamanuensis ved Institutt for allmenn-og samfunnsmedisin. Universitetet i Oslo og fastlege ved Kurbadet legesenter.

\section{Oppgitte interessekonflikter: Ingen}

\section{Litteratur}

1. Winther RB, Bramness JG. Legemiddelshopping av vanedannende medikamenter i Norge. Tidsskr Nor Legeforen 2009; 129: 517-20.

2. Bruk av benzodiazepiner. Konsensuskonferanse. Oslo: Norges forskningsråd, 1996.

3. Dybwad TB, Kjølsrød L, Eskerud J et al. Why are some doctors high-prescribers of benzodiazepines and minor opiates? A qualitative study of GPs in Norway. Fam Pract 1997; 14: 361-8

4. Dybwad TB, Sundene G, Eskerud J et al. Tilsyn med B-preparatforskrivningen En registreringsundersøkelse av B-preparater i Oslo og Akershus. Tidsskr Nor Lægeforen 1994; 114: 3207-10.

5. Antibiotikasenteret for primærmedisin. www.antibiotikasenteret.no (29.1.2009)

6. Gonzales R, Corbett KK, Wong S et al. «Get smart Colorado»: Impact of a mass media campaign to improve community antibiotic use. Med Care 2008; 46: 597-605. 